\author{
"Friends, today, at this hour, \\ our great chief is being looked \\ upon by Monito. He knows \\ that he has led the life of \\ service to his people. He sacrificed \\ his life for the country he loved. \\ We realize that the Great Spirit \\ is with us at this hour, recciving \\ unto his folds our great clìef and \\ his blessings rest upon his people. \\ He will not live amidst evils \\ and temptations but will \\ dwell in the life of continuous \\ happiness where the Great Spirit \\ places his children in the great \\ beyond. It is we who are living \\ that must often ask blessings. He, \\ our great chief, has set us the example, \\ if we all follow, we will meet \\ our great chief in heaven above."
}

\title{
RECLAIMED AREAS AND IOWA AREAS
}

Contrast between the physical resources of Iowa and the West is often easy to state and to illustrate. Natural resources in Iowa compared with the artificial resources in the West, suited to the habitation of man and his engagement in agricultural pursuits, are interesting to consider in the following instance.

The Arrow Rock dam in Idaho, one of the great government reclamation projects, is the loftiest dam in the world. One great journal asserts that upon the formal dedication of this dam there was added a total farm area of 243,000 acres-"an empire in itself." A million tons of concrete 351 feet high, a masterpiece of engineering, "impound behind it the waters that raise mortgages and will repay its cost in a few years."

The Iowa Department of Agriculture informs us that in our state the average in each of our 99 countics is 339,216 acres actually in farming lands, after the deduction of waste land, timber, roadways, farmsteads, cities, and towns.

In comparing this 339,216 acres in Iowa farms "raising mortgages" in each county, with the 243,000 acre "empire" added in an Idaho dedication, we are aware of the humor in the observation 


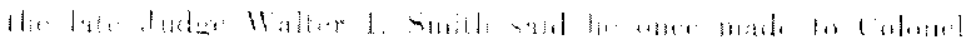

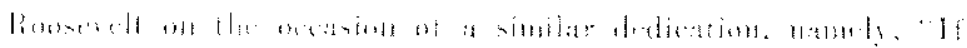

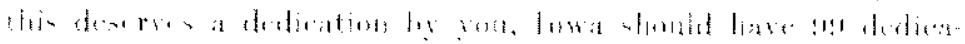

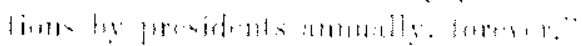

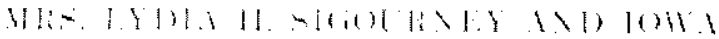

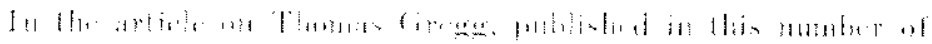

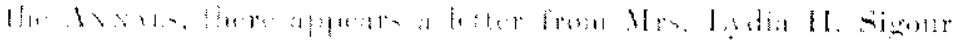

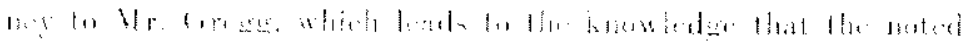

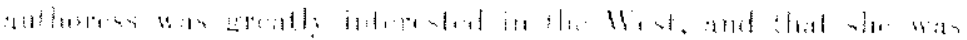

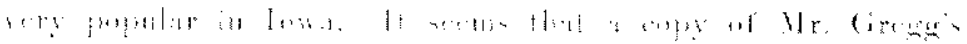

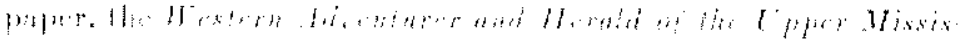

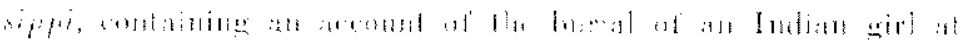

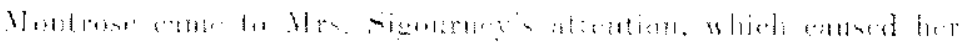

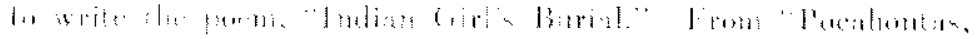

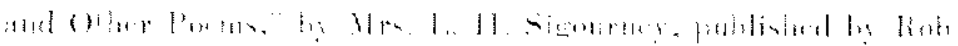

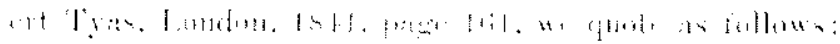

\section{|บओ।}

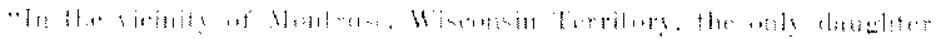

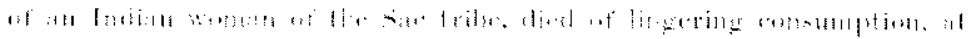

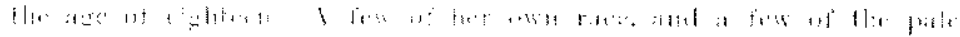

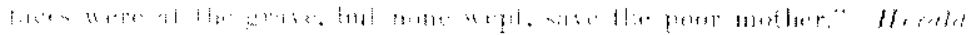

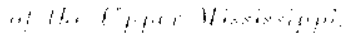

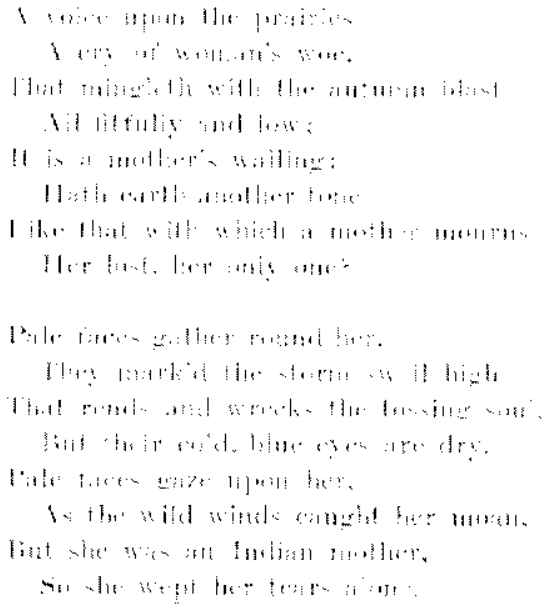


Copyright of Annals of Iowa is the property of State of Iowa, by \& through the State Historical Society of Iowa and its content may not be copied or emailed to multiple sites or posted to a listserv without the copyright holder's express written permission. However, users may print, download, or email articles for individual use. 